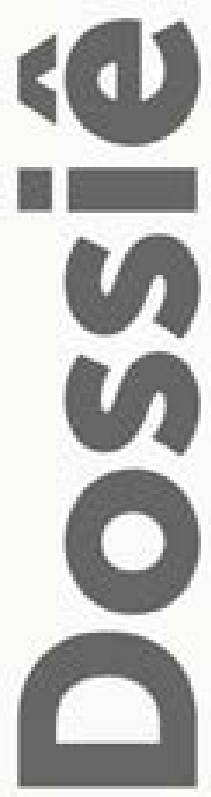

\title{
Os guardiões de pedra da cidade dos mortos: escultura tumular na Manaus da belle époque
}

\author{
The stone guardians of the city of the dead: \\ tomb sculture in Manaus of the belle époque
}

\section{RESUMO}

Este artigo é parte de uma investigação maior que busca, por meio do método analítico de Erwin Panofsky (1892-1968), estudar aspectos iconográficos e iconológicos de um grupo selecionado de esculturas tumulares do período da belle époque, presentes no Cemitério Municipal de São João, na cidade de Manaus. Para a seleção das esculturas consideramos o aspecto temporal e o tipológico, que possuem a figura antropomórfica em comum. Entre essas, imagem mais presente é a do anjo, comumente entendida, como guardiã dos túmulos. Entre fins do século XIX e inícios do XX, sua representação passa por transformações, que the conferem aspectos cada vez mais humanizados. No atual momento da pesquisa, é possível confirmar a presença de um programa estético vinculado a valores socialmente vigentes no século XIX e a adesão ao projeto de modernidade daquela época.

Palavras-Chave: Arte Tumular - Cemitério - Iconologia - Economia da Borracha - Amazonas

\begin{abstract}
This article is part of a larger investigation that seeks, through the analytical method of Erwin Panofsky (1892-1968), to study iconographic and iconological aspects of a selected group of tomb sculptures from the belle époque period, present in the Municipal Cemetery of São João, in the city of Manaus. For the selection of sculptures, we consider the temporal and typological aspects, which share the anthropomorphic figure. Among these, the most present image is that of the angel, commonly understood, as guardian of the tombs. Between the end of the 19th century and the beginning of the 20th, his representation went through transformations, which gave him increasingly humanized aspects. At the present moment of the research, it is possible to confirm the presence of an aesthetic program linked to socially valid values in the 19th century and the adherence to the modernity project of that time.
\end{abstract}

Keywords: Tumular Art - Cemetery - Iconology - Rubber Economy Amazonas

* Doutor em Ciências Musicais Históricas pela Universidade de Coimbra. Docente do Programa de Pós-Graduação em Letras e Artes da Universidade do Estado do Amazonas (PPGLA-UEA). CV: http://lattes.cnpq.br/3633926295444257

** Mestranda do Programa de Pós-Graduação em Letras e Artes da Universidade do Estado do Amazonas (PPGLA-UEA). CV: http://lattes.cnpq.br/3075467101336707 


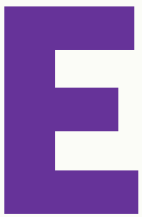

ste texto apresenta resultados preliminares do estudo iconográfico de um grupo escultórico tumular do período compreendido entre o final do século XIX e início do XX, no qual Manaus viveu uma belle époque, proporcionada pelo dinheiro da exportação da borracha amazônica. As esculturas pertencem ao Cemitério Municipal de São João e a análise teve por base o método iconográfico de Erwin Panofsky (2017 [1939 e 1955] ${ }^{1}$, p. 64), que propõe etapas de análise para além da descrição formal do objeto artístico. Em termos gerais, propõe aprofundar o contexto de criação e os significados da obra, individualizada ou seu conjunto, para que se compreenda o que ela representa. Para esta pesquisa, "o valor está em reconhecer a relação entre o mundo dos vivos (escultor, ente querido, espiritualidade, etnia etc.) e a natureza transformada (escultura)" (Nabozny e Liccardo, 2017, p. 28). Reconhecido esse elo, busca-se entender o papel que essas obras exercem, como representantes de um pensamento estético e social, no contexto de criação e recepção em que se inserem.

Pedro du Bois se aproxima em linguagem poética dos objetivos desse trabalho, na medida em que desenvolve a ideia das estátuas no meio urbano como guardiãs de um mundo de segredos e mistérios que representam a história (ou as histórias) da cidade, codificada(s) na própria expressão dessas obras. Nas palavras do autor: "Estátuas se coadunam nas cidades / onde se escondem em segredos. / Rearrumam mistérios ao ar livre" (2013, p. 67).

Estudar o modo como as sociedades lidam com a consciência da morte é um dos meios mais fascinantes de se buscar compreendê-las. Para tanto, os cemitérios históricos se consistem num rico terreno de objetos propícios para análise, muitos dos quais ameaçados pela falta de preocupação em preservar essa memória. No caso do estudo aqui proposto, trata-se da memória de um período emblemático para a região amazônica, no qual Manaus viveu seu primeiro grande impulso de urbanização, entre o final do século XIX e o início do XX. Enriquecida pelo dinheiro da exportação da borracha, A cidade passou por transformações pautadas por valores e modelos da modernidade, que teve na implantação do Cemitério Público de São João um de seus expoentes. A modernidade aqui é entendida como vinculada à Idade Moderna, ${ }^{2}$ com sua ideia de história linear, que sustenta a noção de progresso e gera a convicção de emancipação do indivíduo, amparada no acesso aos bens e serviços proporcionados pela industrialização entre os séculos XVIII e XIX, que permitiu uma ascensão da classe burguesa.

Constata-se de antemão que, apesar do crescimento das pesquisas cemiteriais nos últimos anos, observa-se que os estudos locais ainda não têm refletido a importância mais alargada de sentidos do espaço cemiterial como documento histórico, geográfico e artístico.

1 O método foi detalhado pela primeira vez na obra Studies in iconology: themes in the art of the renaissance, de 1939 (referenciada aqui sua 2 a edição portuguesa de 1995), sendo depois retomado em Meaning in the visual arts, originalmente publicada em 1955.

2 A discussão iniciada por Lyotard (1991[1975]) sobre os limites da modernidade e suas características fundamentais, de modo a estabelecer uma pós-modernidade, recebeu a colaboração de importantes nomes da estética, da filosofia e da sociologia, dentre os quais Gianni Vattimo (2002 [1985]; 1992 [1989]) e Boaventura Sousa Santos (2010), que discutem e consolidam a noção de modernidade, compreendida como o período entre o século XIV tardio e a viragem do século XIX ao XX. Conforme tais autores, o projeto da Modernidade nasce com a expansão do Humanismo, por volta do século XIV, em direção a uma emancipação que não se revelaria individual nem de classe, inclusive após os eventos políticos e os aportes filosóficos do século XIX, por ter se vincado na tecnologia e diminuído a carga humanista da formação (esta também uma estratégia formativa a partir da reforma napoleônica da educação no século XIX), resultando num esvaziamento das verdades e do pensamento globalizante, em razão de uma heterotopia a ser negociada, posto tratar-se de uma forte tendência em curso. 
De qualquer modo, trata-se de temática ainda pouco explorada. Pretende-se, portanto, buscar contribuir para a visibilidade deste patrimônio, promovendo uma discussão sobre ele. Nos tópicos seguintes serão apresentadas, primeiramente, reflexões sobre a condição humana ligada à morte e sua ritualização, bem como sua relação com a arte, destacando-se o papel da escultura tumular no contexto da sociedade ocidental, especificamente aquela do período em que se situa a criação das obras desta análise. Em seguida, serão analisadas as características histórico-geográficas de Manaus, destacando-se as condições econômicas e culturais que moldaram a sociedade que foi o público receptivo das obras elencadas. Por fim, apresentamse os resultados preliminares da pesquisa em curso, a partir da análise dos principais temas observados nas esculturas.

\section{Reflexões sobre a morte e a arte}

"Suponhamos que as pessoas vivam eternamente", assim Alan Lightman (2014, p. 68) propõe a existência fictícia de um mundo em que não há morte natural. As pessoas, divididas entre as que vivem intensamente o agora e as que aproveitam o tempo em abundância para fazer tudo depois, de nenhuma forma se sentem completas, pois uma vida com tantas possibilidades, tanto passado, se torna um peso. Algumas, sufocadas por esse peso, acabam por escolher a morte como o melhor jeito de viver, extinguindo suas vidas infinitas.

O mundo proposto por Lightman sintetiza a ideia da morte como parte fundamental da existência humana. Soa banal afirmar que a morte é a única certeza que se tem na vida, mas quando se reflete, é possível perceber o quanto a consciência da própria finitude é o que move a humanidade, o que rege seus grandes feitos. É como modo de lidar com sua condição que o homem desenvolve ritos para explicar, lamentar, celebrar a morte. Desse modo, julgando olhar para a morte, o homem olha para si próprio, sua própria imagem, seu próprio mito (Morin, 1997, p. 19).

Morin considera que é com o início da preocupação com a morte e os mortos, representada pelos mais antigos registros de sepultamento, que o homem atravessa a fronteira do mundo das feras, rumo a um estado de consciência que o caracteriza como o que é (1997, p. 23). A sepultura, embora não seja o único destino possível dos mortos nos ritos fúnebres, é considerada "o dado primeiro, fundamental e universal da morte humana" (Morin, 1997, p. 24), pois acaba por se caracterizar como o testemunho mais sólido da preocupação com a morte, das ideias e crenças em torno desta. A sepultura, acima de tudo, constitui um marco físico da morte no espaço, cristalizando informações culturais sobre a sociedade representada pelo morto.

Segundo Campbell, a prática do sepultamento teria se iniciado com o homo neanderthalensis por volta de 200.000 a 75.000 a.C. (2005, p. 67). O ato de enterrar os mortos possivelmente ligava-se a uma visão da terra como uma grande mãe, um útero que lhes concedia a vida e o sustento. Provisões e animais sacrificados encontrados dispostos de leste para oeste, próximos aos esqueletos enterrados indicariam uma crença numa vida após 
a morte, um despertar ou, ainda, um possível renascimento, dada a posição fetal de alguns desses esqueletos.

Jaffé discute a interligação da história da arte e da religião por meio do uso da pedra no contexto funerário desde os tempos pré-históricos (2008, p. 312). Ainda em seu estado bruto, esta tinha um alto valor simbólico para as sociedades antigas e primitivas, sendo muitas vezes considerada lugar de morada de divindades e espíritos, compondo objeto de veneração religiosa, marco espacial e lápide. "Podemos considerar esse emprego da pedra como uma forma primitiva de escultura - uma primeira tentativa de dar à pedra maior poder expressivo do que o oferecido pelo acaso ou pela natureza" (Jaffé, 2008, p. 313).

A arte também passa a se fazer presente na sepultura, como forma de preservar a identidade do morto de algum modo ou comunicar algo a seu respeito. Franco destaca a pintura policrômica presente em sepulturas a partir do neolítico (entre 12 e 10 mil a.C.) (Franco, 2010, p. 50). São pinturas encontradas nas entradas de cavernas e sobre pedras tumulares, em que muito se utilizava do ocre vermelho e havia um predomínio de representações geométricas e cruzes. Tais vestígios parecem "fornecer indícios da importância do registro em torno da morte. A marca - seja ela qual for - determina algo, eternizando um dado qualquer sobre o morto (data, nome, dizeres, símbolos, acontecimentos)" (Franco, 2010, p. 50).

Tomando consciência da morte ou justamente por esse motivo, o homem teria deixado de acreditar que ela significasse de fato o fim de sua existência, em parte motivado por sonhos que pouco diferiam de visões. A ideia de que o morto de alguma forma continuava a existir, sem as oportunidades e ao mesmo tempo sem as limitações dos vivos, teria provocado grande temor no homem primitivo, o que acabou por se transformar num sentimento religioso, que persiste à medida em que este começa a se organizar de forma socialmente mais complexa. Inspirado por esse temor, o homem cuida de seus mortos, tanto visando rendê-los quanto satisfazê-los, de todo modo tornando-os inofensivos e, com o tempo, uma espécie de aliados no mundo sobrenatural (Panofsky, 1992, p. 10).

"Deixar os mortos felizes significava, é claro, prover-lhes com o que se pode chamar de necessidades do pós-vida, ou seja, tudo de que eles costumavam precisar ou apreciar quando vivos" (Panofsky, 1992, p. 10). ${ }^{3}$ Segundo Panofsky, inicialmente isso era praticado de forma unicamente literal, pois comida, bebida, ferramentas, ornamentos e, em alguns casos, até escravos eram enterrados junto ao defunto, para servi-lo em sua nova condição. Mas, com o tempo, passou-se a conferir à pedra a tarefa de prover as necessidades do morto por intermédio da arte.

Ainda para Panofsky (1992, p. 16), a escultura tumular se consolida ao longo da antiguidade com o papel de representar o morto e aquilo que se pretendia preservar dele e para ele. Dessa forma, a escultura adquire caráter retrospectivo ou prospectivo, ora exaltando da melhor forma o passado, a vida vivida pelo defunto, ora servindo como um tipo de vaticínio de seu futuro, daquilo que o esperava ou melhor, do que se esperava para o que vinha depois

3 Trecho original: "The means of making the dead happy were, of course, to provide them with what may be called the necessities of afterlife, that is to say, with everything they used to need or enjoy when alive." (Tradução dos autores). 
de sua morte. Em alguns casos, a escultura podia ainda representar uma junção dos dois casos.

De modo geral, os temas presentes na escultura tumular, desde tempos remotos, ajudam a compreender as crenças, valores, anseios da(s) sociedade(s) na medida em que esses são expressos e eternizados na perenidade do mineral em que são produzidos. Recorrendo novamente à poesia de Bois, "A estátua representa a ação intencional da sobrevivência" (2013, p 84).

A escultura tumular é objeto marcante de práticas mortuárias que se consolidam no século XIX na sociedade cristã ocidental, baseadas na ideia de cemitério como lugar reservado aos mortos, à parte do mundo dos vivos. Nesse momento há, de certa maneira, uma retomada dos costumes artísticos funerários da antiguidade, uma vez que se recupera a individualidade do morto numa ruptura com a cultura fúnebre medieval de enterramento nas igrejas, que fazia coabitar vivos e mortos nos centros das cidades, conforme descrito por Ariès (2017, p. 41), um dos grandes estudiosos da morte.

A sociedade recomposta a partir a partir de nova etapa da ascensão burguesa, que se dá a partir do fim do século XVIII, imprime outro cuidado com os mortos. Para a burguesia do século XIX, o culto da morte caracteriza-se pelo culto da morte do outro, visando "perenizar o individualismo do homem, recém-valorizado após a morte; romper o anonimato das pessoas que passam a promover-se, distinguir-se dos demais" (Borges, 2002, p. 130-131). Na cidade dos mortos ergue-se um espelho do seu oposto - a cidade dos vivos - onde as famílias burguesas expressam seus gostos, suas pequenas fantasias, que se convoca a arte para representar e imortalizar.

\section{Manaus dos vivos e dos mortos}

A capital do Amazonas, atualmente com uma população de mais de 2 milhões de habitantes, em $11.401 \mathrm{~km}^{2}$ de área, ${ }^{4}$ tem sua origem num forte erguido em 1669 na foz do rio Negro, com o objetivo de firmar o domínio da Coroa portuguesa para além dos limites de Tordesilhas. A Fortaleza de São José da Barra do Rio Negro "tratava-se de uma obra rústica, de forma quadrangular, feita de grossas paredes de pedra e barro, com uma das faces para o rio" (Bittencourt, 1999, p. 3).

O povoado que surge nos arredores do forte cresceu lentamente ao longo de muitos anos, passando a vila em 1832, chegando à cidade apenas em 1848, instituída capital da província do Amazonas quando da criação desta em 1850 (Bittencourt, 1999, p. 12). Na segunda metade do século XIX, no entanto, esse cenário mudou, à medida que cresce a arrecadação da província, em decorrência da exportação da borracha natural silvestre da Amazônia, dominante no suprimento do material altamente necessário para as indústrias europeias e norte-americanas em plena expansão.

"Manaus tornara-se uma cidade moderna, com uma aparência mais europeia: servida

4 Estimativa do Instituto Brasileiro de Geografia e Estatística - IBGE de 2012. Disponível em: < https://cidades.ibge. gov.br/brasil/am/manaus>. Acesso em: 29/08/2019. 
por alguns dos melhoramentos e serviços típicos das prósperas e modernas sociedades" (Mesquita, 2006, p. 121). No século XIX, a ideia de modernidade como sinônimo de progresso envolvia, dentre outros aspectos, uma série de medidas que visavam estabelecer um ambiente urbano mais salubre, baseado em leis sobre higiene que tornavam as cidades um espaço mais controlado, afastando os chamados medos urbanos, tudo aquilo que ameaçava a ordem do espaço regido pela racionalidade positivista (Coe, 2008, p. 9).

Dentre os medos urbanos, incluíam-se a morte e os mortos, cujo costume iniciado na Idade Média ditava que fossem sepultados no solo sagrado das igrejas (Ariès, 2017, p. 44). A Modernidade provocou então uma reestruturação na sociedade, que passou a trabalhar "com o confronto dialético de duas realidades conceituais de vida: a cidade dos mortos e a cidade dos vivos" (Borges, 2002, p. 130). Com a ruptura entre essas duas realidades, aos mortos é conferido um espaço à parte, em que são organizados de modo a espelhar a cidade dos vivos, dispostos em moradas que reproduzem o que se considera como cidade ideal, num culto familiar que exprime a ideia da morte burguesa.

Manaus tem seu primeiro cemitério público construído em caráter provisório por trás da Capela de Nossa Senhora dos Remédios, localizada numa área ainda um tanto remota da cidade, em 1854, dois anos após a instalação da província do Amazonas. ${ }^{5}$ A capital da nova província dava então seus primeiros passos em busca do ideal de modernidade urbana ocidental. Duarte (2009, p. 147) aponta que, em dois anos, uma epidemia de febre amarela provocou a desativação deste cemitério e a construção de um novo, o Cemitério de São José. Na década de 1870, outra epidemia, agora de varíola, assolou a cidade e foi aberta nova necrópole, próxima ao hospital construído para tratar as vítimas. Mortos por epidemias continuaram a ser enterrados neste cemitério até o início do século $X X$, mas o Cemitério de São José foi desativado em 1891, com a inauguração de mais um campo santo.

O Cemitério Municipal de São João iniciou suas atividades em 5 de abril de 1891, localizado numa área que marcava os limites da cidade, hoje bairro Nossa Senhora das Graças (Duarte, 2009, p. 147). Construído no auge do Período da Borracha, Nagel destaca o papel deste cemitério, de servir não apenas como solução para o destino dos mortos numa cidade que crescia rapidamente, como também como espaço necessário de afirmação social, declaradamente pensado para receber jazigos e monumentos que viriam a celebrar aqueles que queriam se servir do melhor a ser oferecido por uma cidade moderna (Nagel, 2011, p. 5).

O Cemitério de São João foi então estruturado numa área de arrabaldes da antiga urbe manauara (Figura 1), próximo da Vila Municipal, um bairro mais afastado, projetado para construções elegantes, grandes áreas verdes de entorno e arruamento largo em distribuição cartesiana, o que pode ser verificado no círculo que se encontra na parte superior do mapa que compõe a Figura 2, indicando o chamado "Cemitério Novo" (neste mapa podemos identificar que sua posição se distancia significativamente da área mais antiga e populosa na qual o Cemitério Velho se encontrava, aqui sinalizado com o círculo na parte inferior desta figura). O destaque topográfico deste conjunto urbano conferiria a visibilidade e a contemplação

5 Estrella do Amazonas. Cidade da Barra, 24 de Junho de 1854. Disponível em: <http://memoria.bn.br/DocReader/ DocReader. aspx? bib=213420\&PagFis=1085>. Acesso em: 26/12/2019. 
espiritual propostas pela sobredita ideia de afirmação social e cultural.

Figura 1. Vista do Cemitério Municipal de São João, 1901

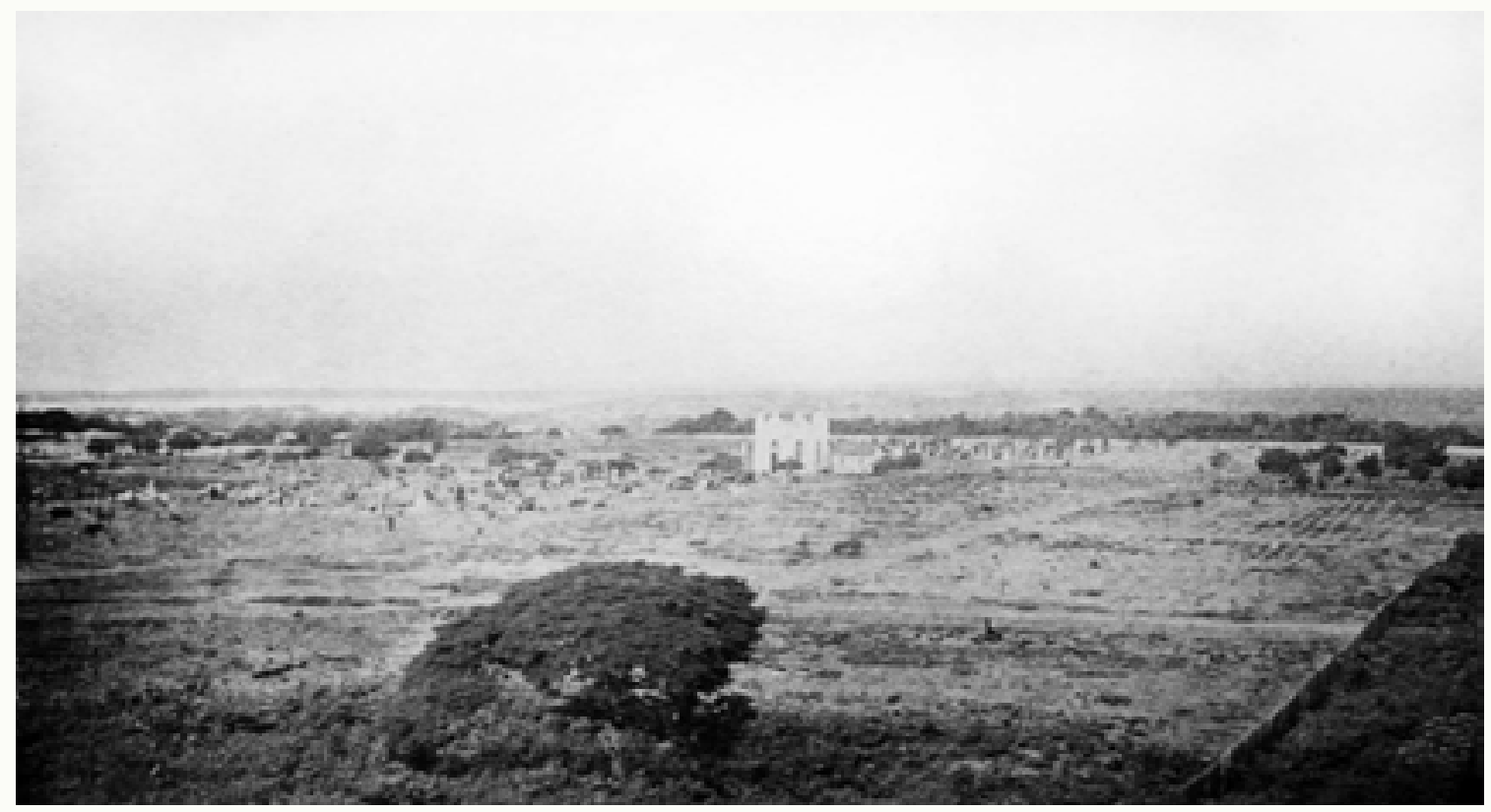

Fonte: Relatório do superintendente municipal Arthur César Moreira de Araújo, $1901 .^{6}$

6 Acervo Digital do Instituto Durango Duarte. Disponível em: <https://idd.org.br/acervo/cemiterio-sao-joaobatista-2/>. Acesso em: 30/12/2019. 
Figura 2. Planta de Manaus e arrabaldes, 1906

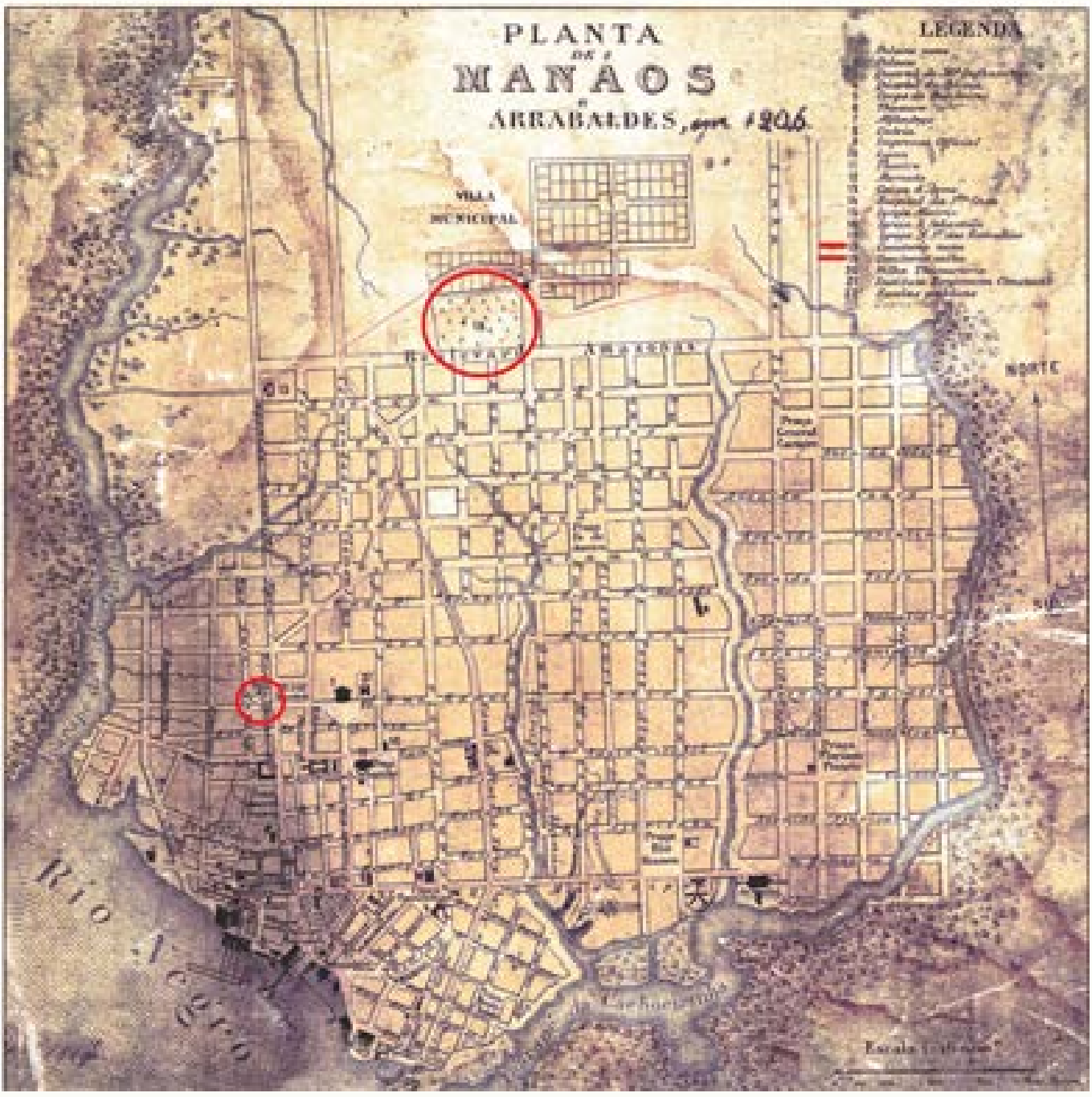

Fonte: Acervo Digital do Instituto Durango Duarte, a partir de acervo do IGHA. ${ }^{7}$

Em nossa atualidade, o cemitério de São João conta com 24 quadras, distribuídas em 101.128,32 $\mathrm{m}^{2}$ de área ${ }^{8}$ (Figura 3). O local afastado em que a cidade dos mortos foi erigida no final do século XIX tornou-se um dos pontos mais movimentados de Manaus, a partir da segunda metade do século $X X^{9}$. Seus dois portões principais se abrem para duas grandes avenidas e suas perpendiculares, que produzem um ruído urbano, contrastante com a calmaria entre os muros da necrópole, tombada como Monumento Histórico do Estado do Amazonas em 14 de junho de 1988, pelo decreto de lei 11.198 (Duarte, 2009, p. 149).

7 Disponível em: <https://idd.org.br/acervo/planta-de-manaos-e-arrebaldes-levantada-em-1906/>. Acesso em: 30/12/2019.

8 Secretaria Municipal de Limpeza Urbana - SEMULSP. Cemitérios públicos de Manaus. 2012. Disponível em: < $\underline{\text { http:// }}$ semulsp.manaus.am.gov.br/cemiterios/>. Acesso em: 30/08/2019.

9 Com a economia enfraquecida desde o declínio da exportação da borracha nos anos 1910, a cidade volta a crescer aceleradamente a partir da implantação da Zona Franca em 1967. 
Figura 3. Planta do Cemitério Municipal de São João

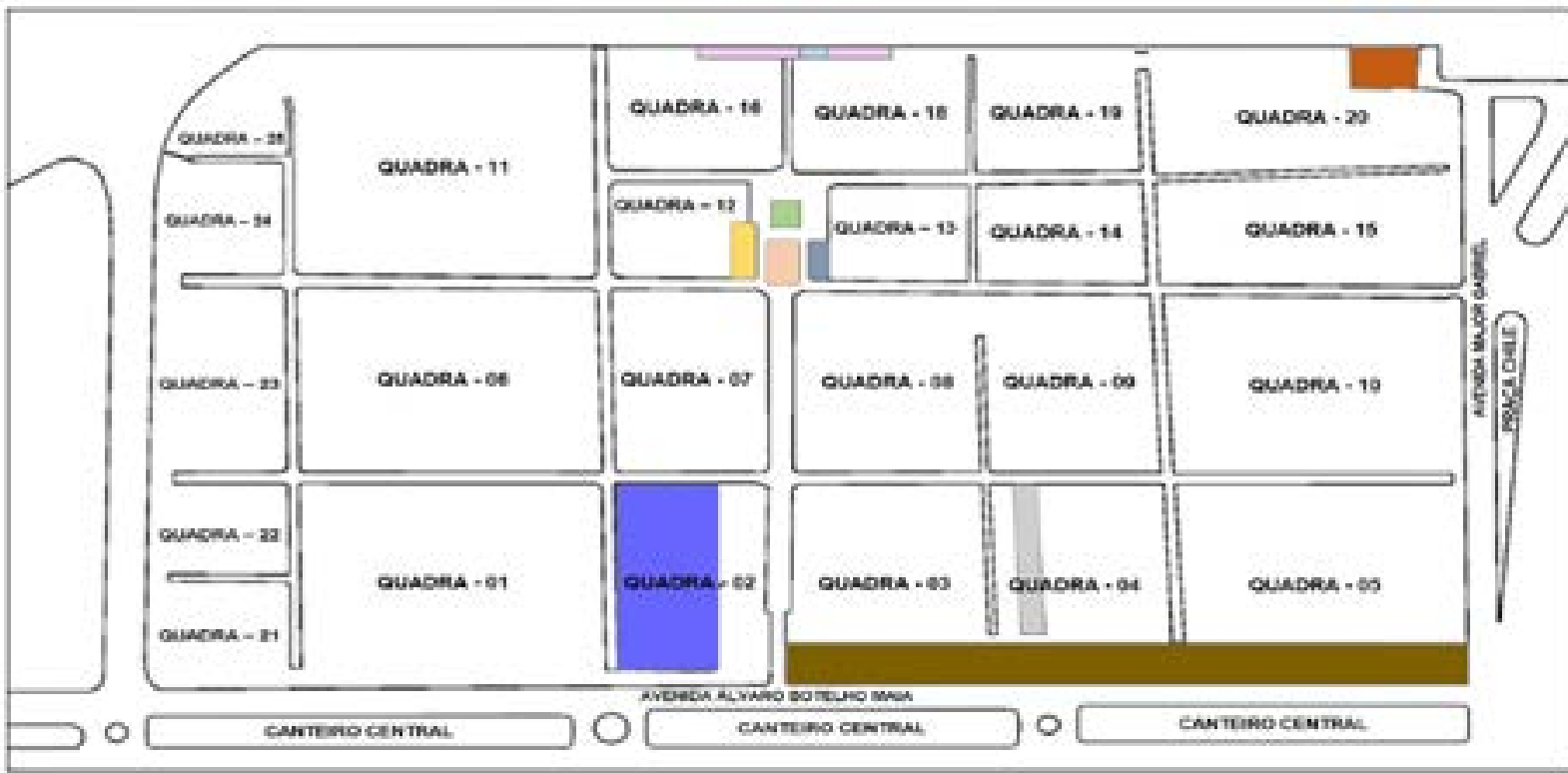

Lecovar:
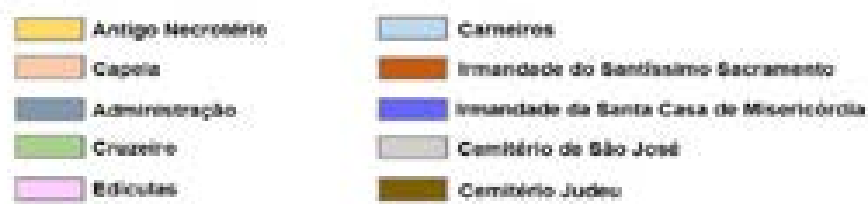

Fonte: Adaptação de Barata Neto (2012, p. 28).

Segundo Borges, a cidade dos vivos, organizada a partir dos preceitos da modernidade prezava por "novos modelos gerais de urbanização e com novas tipologias de serviços, como residências, teatros, hospedarias e fábricas. As construções, numa primeira instância visavam ao bem-estar coletivo e ao progresso, advindos da Revolução Industrial" (Borges, 2002, p. 147).

Entre os novos serviços típicos das civilizações modernas dos quais Manaus passou a usufruir, merece destaque os trabalhos de marmoraria, uma vez que o mármore era o material mais frequente na composição da estatuária dos cemitérios ocidentais no período. Segundo Borges (2002, p. 53), os serviços prestados aos cemitérios secularizados - juntamente com o trabalho nas construções ecléticas - conferia ao marmorista uma posição privilegiada no final do século XIX: "Em resumo, pode-se considerar o marmorista ou artista-artesão do fim do século XIX e início do século XX como aquele artista mediador, que está empenhado em reunir a arte e a sociedade, por meio dos seus trabalhos artísticos" (Borges, 2002, p. 55).

Em Manaus, a Marmoraria Ítalo-Amazonense destacou-se pelos anúncios e notícias em periódicos e almanaques (ver Figura 4). Inaugurada em 1898, viria a se constituir de modo marcante para a estatuária tumular no Amazonas. Seu nome está gravado em várias das sepulturas encontradas no Cemitério de São João. As observações realizadas em campo e a leitura de periódicos permitem destacá-la como uma das principais responsáveis por legar um 
grande acervo de patrimônio artístico e histórico presente nessa Manaus dos mortos.

É possível que a chegada da marmoraria à cidade tenha contribuído para tornar mais democrático o acesso às peças de decoração tumular, uma vez que facilitava a aquisição de itens em variados tamanhos e preços, sem a necessidade de importar diretamente a obra de outro estado ou país. Com isso, tornava-se mais difuso também o padrão estético oitocentista sobre a ideia de um mundo espiritual mais ocidentalizado, à maneira do hemisfério norte.

Figura 4. Anúncio da Marmoraria Ítalo-Amazonense ilustrado com exemplos de mausoléus de seu catálogo

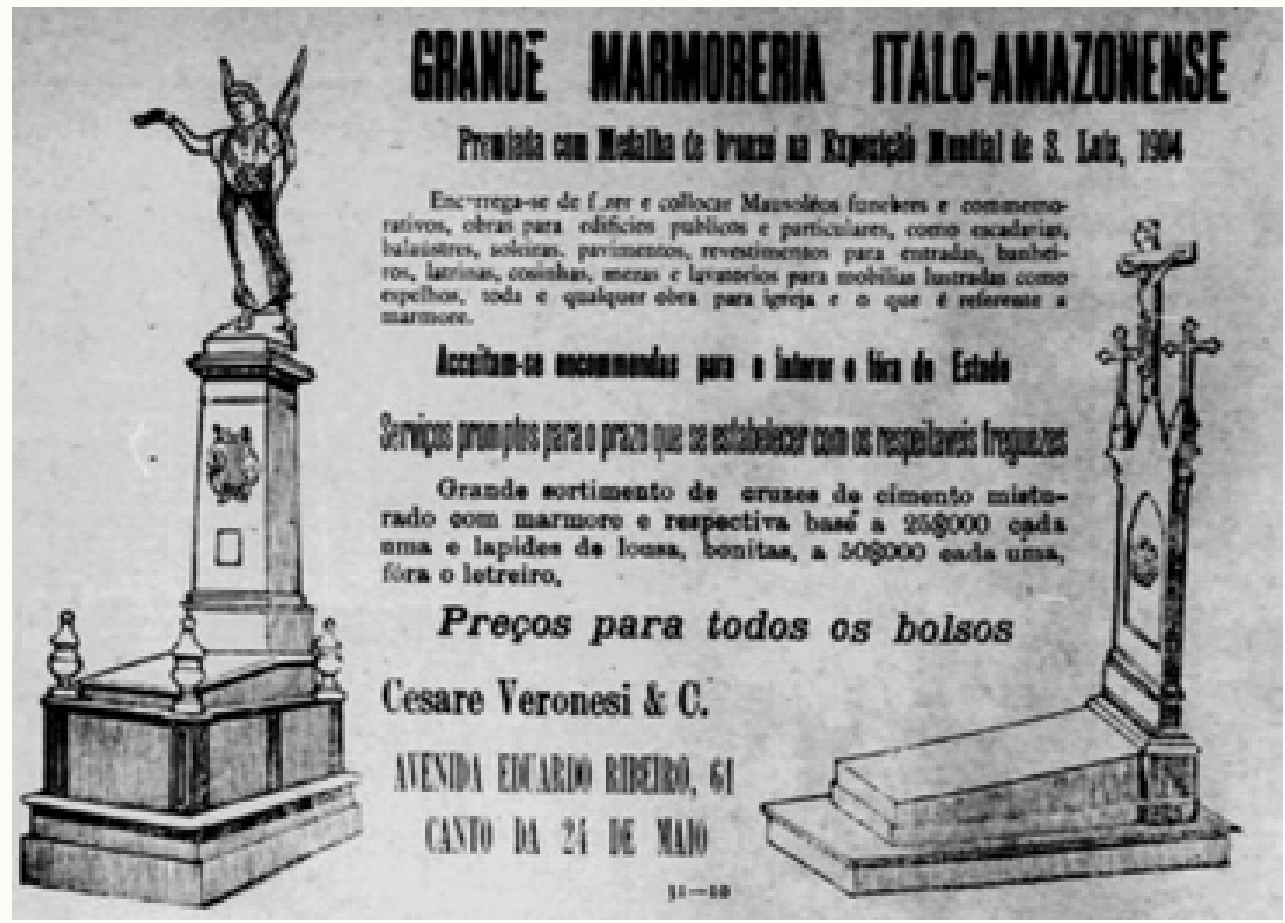

Fonte: Jornal do Commercio. Manaus 18 de outubro de 1908, p. $7^{10}$

Desde a sua fundação, o proprietário da Marmoraria Ítalo-Amazonense, foi Cesare Veronesi (? - 1941), chegado à cidade naquele mesmo ano. ${ }^{11}$ Esteve sempre identificado como dono deste negócio e referido por vezes como industrial e engenheiro. A dimensão a que chegou sua marmoraria deve-se ao empenho profissional. A firma importava mármore diretamente de Carrara e, com alguma frequência, Veronesi viajava à Itália para tratar de encomendas, tanto de pedra bruta ou talhada, como de obras de arte. ${ }^{12}$ Quando ausente, Veronesi deixava um representante legal e comercial no escritório na praça de Manaus, enquanto no estabelecimento seu chefe de oficina se encarregava de suprir as encomendas. Eram em princípio sempre membros da comunidade italiana de Manaus. Entretanto, houve uma frustrante experiência em 1904, quando o encarregado da marmoraria, Angelo Anello

10 Disponível em: <http://memoria.bn.br/DocReader/170054_01/6326>. Acesso em: 30/12/2019.

11 Jornal Imparcial. Manaus, 5 de Maio de 1918, p. 4. Disponível em: <http://memoria.bn.br/DocReader/721212/242>. Acesso em: 13/09/2019.

12 Jornal Quo Vadis? Manaus, 19 de Março de 1903, p. 3. Disponível em: <http://memoria.bn.br/ DocReader/363154/394>. Acesso em: 30/12/2019. 
se apossou do saldo de todos os negócios durante a viagem de Veronesi. ${ }^{13}$ Quando levou os trabalhos da firma para as exposições universais de Roma e Turim, em 1911, deixou a marmoraria aos cuidados de Jacob de Oliveira Rocha e Domingos Gomes Coutinho, que eram na altura seus empregados mais experientes e confiáveis. ${ }^{14}$

Os anúncios de chegada ao porto de Manaus de materiais importados por Veronesi informam dezenas de pedras ou, até, excedendo mais de uma centena de uma só vez. A progressiva expansão do negócio fez com que se mudasse mais de uma vez de endereço, em busca de espaço e de visibilidade. Saiu da Rua Saldanha Marinho em 1898, para ocupar endereço na principal vitrine de negócios da cidade, Av. Eduardo Ribeiro, ainda em $1903 .{ }^{15}$

O sucesso da Marmoraria Ítalo-Amazonense foi eliminando gradativamente a concorrência: em 1906 comprou a Marmoraria Luso-Brasileira, de Victorino José Romão, instalada na Av. Eduardo Ribeiro, no 44 e alargou o espaço físico e comercial do estabelecimento. ${ }^{16}$ A firma possuía ainda o Governo do Estado do Amazonas como um de seus clientes, pois são frequentes as publicações de despacho sobre ordem de pagamento ou reconhecimento de dívida do erário público estadual com os serviços de Veronesi. A fama da oficina também foi fruto de investimento do proprietário. A Marmoraria Ítalo-Amazonense tomou parte de várias exposições nacionais e mundiais, dentre elas: a Exposição Mundial de Saint Louis - $1904,{ }^{17}$ onde obteve uma medalha de bronze; a Exposição Nacional do Rio de Janeiro - $1908{ }^{18}$ e a Feira Internacional de Bruxelas - 1910. ${ }^{19}$

Algumas obras de autores italianos que se identificam hoje no Cemitério de São João foram intermediadas pela firma de Veronesi, embora outras tenham chegado por mãos de terceiros, revelando aspectos da alta competitividade do negócio, como é o caso que envolveu a escultura do genovês Pietro Bacigalupo (1875-1924). As credenciais de Bacigalupo, para além de endereço comercial e um nome de família ligado às artes em sua terra natal envolvem o estudo da escultura na Academia de São Petersburgo, onde trabalhou durante vinte anos no Palácio de Inverno, produzindo vasta decoração. ${ }^{20}$ Para Cesare Veronesi, Bacigalupo foi, na melhor hipótese, um artista menor que subcontratava obras, tomava as obras de outros como suas. Portanto, possuía reputação "duvidosa" e "imerecida", segundo palavras do empresário, como se verifica a seguir:

13 Jornal do Commercio (doravante JC). Manaus, 13 de Outubro de 1904, p. 3. Disponível em: <http://memoria. bn.br/DocReader/170054_01/>. Acesso em: 13/09/2019.

14 JC. Manaus, 20 de maio de 1911, p. 8. Disponível em: <http://memoria.bn.br/DocReader/170054_01/10573> Acesso em: 13/09/2019.

15 Jornal Quo Vadis? Manaus, 12 de Maio de1903, p. 4. Disponível em:<http://memoria.bn.br/DocReader/363154/573>. Acesso em: 13/09/2019

16 JC. Manaus, 18 de abril de 1906, p. 2. Disponível em: <http://memoria.bn.br/DocReader/170054_01/3112>. Acesso em: 13/09/2019.

17 Correio do Norte. Manaus, 04 de Fevereiro de 1911, p. 3. Disponível em: <http://memoria.bn.br/ DocReader/228095/2363>. Acesso em: 13/09/2019.

18 JC. Manaus, 06 de Outubro de 1907, p. 1. Disponível em: <http://memoria.bn.br/DocReader/170054_01/4812>. Acesso em: 13/09/2019.

19 Mensagem do Governador do Estado do Amazonas Coronel Antonio Clemente Ribeiro Bittencourt. Lista conferida aos representantes e expositores do Amazonas na Feira Internacional de Bruxelas de 1910. Manaus: Secção de Obras da Imprensa Oficial, 10 de Julho de 1910, p. 339. Disponível em: <http://memoria.bn.br/ DocReader/872784/3103>. Acesso em: 13/09/2019.

20 CONTI, Simonetta. L'amore che sussurra. La stampa. 18 de Fevereiro de 2013. Disponível em: <https://www. lastampa.it/torino/2013/02/18/news/l-amore-che-sussurra-1.36121943>. Acesso em: 04/09/2019. 
O escultor Bacigalupo

A pedido do conhecido patrício Antonio Borsa, que tem por vezo o engrossamento e por vício o exhibicionismo, veio publicado n'O Tempo, de 2 do corrente, o retrato do Sr. Pietro Bacigalupo, "Esculptor exímio, premiado em diversos concursos na Itália, autor do único monumento de arte existente na nossa necrópole, representando a FÉ".

Entretanto o sr. Bacigalupo nunca poderá criar obras de valor, porque nunca foi moldador em barro. É um dos taes artistas que, tendo uma encomenda, fazem-na de outrem ou compram-na já feita, e se lhes pedirem esboçar um simples retrato em barro... dão parte de doente.

A arte não consiste em reproduzir uma obra que está em commercio, vendendo-se em dezenas de copias em todos os tamanhos, mas sim em concebe-la e cria-la, e ao sr. Bacigalupo lhe falta o valor para tanto. Monumentos há nesta necrópole, poucos ainda em verdade, que são verdadeiramente únicos no que diz respeito à arte, quer pela execução conforme indicações dos comitentes, quer por terem sido esculpidos por conhecidos professores, realmente laureados em escultura, cujos merecimentos tem sido injustamente atacados pela extemporânea publicação acima que, de certo modo, melindra também as famílias convictas de terem, sobre o tumulo de seus entes queridos, mausoleos dignos sob todos os pontos de vista.

Com respeito aos concursos em que o sr. Bacigalupo tomou parte, conhecemos de um só: o projecto ao General Bolognesi. O "escultor exímio" contractou dois artistas, já melhores que ele, pactuando mesmo no caso que lhe coubesse um segundo prêmio, pagar-lhe-ia o trabalho, e em caso negativo, oferecer-lhe-ia uma ceia. Apresentou o projecto como se fosse seu, pagou... a cela, e espera ainda a láurea de professor que tardará de vir.

De tudo isso temos provas e, embora contra gosto, resolvemos fazer esta publicação tão somente para dar uma satisfação àquelles que nos honraram com suas valiosas encomendas, declarando-lhes que os mausoleos cuja execução nos foi confiada, têm sido esculpidos por artistas de renome, como o professor Franzoni de Carrara e que nunca serão reproduzidos para outros túmulos, ficando assim obras de verdadeiro valor.

\section{Manáos, 6 de Agosto de 1917. \\ Cesare Veronese $\& C^{\underline{a}}\left[\right.$ sic $^{21}$}

Veronesi fazia questão de ressaltar em seus anúncios que os materiais que comercializava eram mármores vindos de Carrara, possuindo catálogo de produtos e variado estoque. $^{22}$ Entretanto, por anunciar-se disponível a todos os bolsos, também contava com

21 Jornal A Capital. Manaus, 07 de Agosto de 1917, p. 2. Disponível em:<http://memoria.bn.br/DocReader/307149/90>. Acesso em: 13/09/2019.

22 JC. Manaus, 06 de abril de 1909, p. 3. Disponivel em: <http://memoria.bn.br/DocReader/170054_01/7054>. Acesso em: 13/09/2019. 
materiais vindos de "jazidas enormes e pouco longe de Manáos"23 e "grande sortimento de cruzes de cimento misturado com mármore [...] e lápides de lousa". ${ }^{24}$

Nem todo o sortimento da Mamoraria Italo-amazonense destinava-se a finalidades tumulares. Consolidada na praça de Manaus, a firma passou a negociar também "obras de Bellas Artes, como de Engenharia, Pinturas a Óleo, Aguarella, a la Guache, e a pasteis, caixas completas para amadores, barro e utencílios para plástica, materiais e utencílios também para bordados de seda, lá, algodão e canotilha, tudo de qualidade superior [sic]". ${ }^{25}$

\section{Laborum meta}

"A última entrada, o último passeio, a nova morada, a placa - laborum meta". 26 "Fim dos Trabalhos", é o que indica em latim a inscrição gravada sobre os portões de ferro do Cemitério Municipal de São João (Figura 5). A expressão leva a refletir sobre o lugar que representa o destino final e inevitável de toda a humanidade, bem como convida a apurar os segredos e mensagens guardados pelas efígies de pedra das habitações fúnebres de figuras de outras épocas.

Figura 5. Letreiro em portal de entrada do Cemitério Municipal de São João

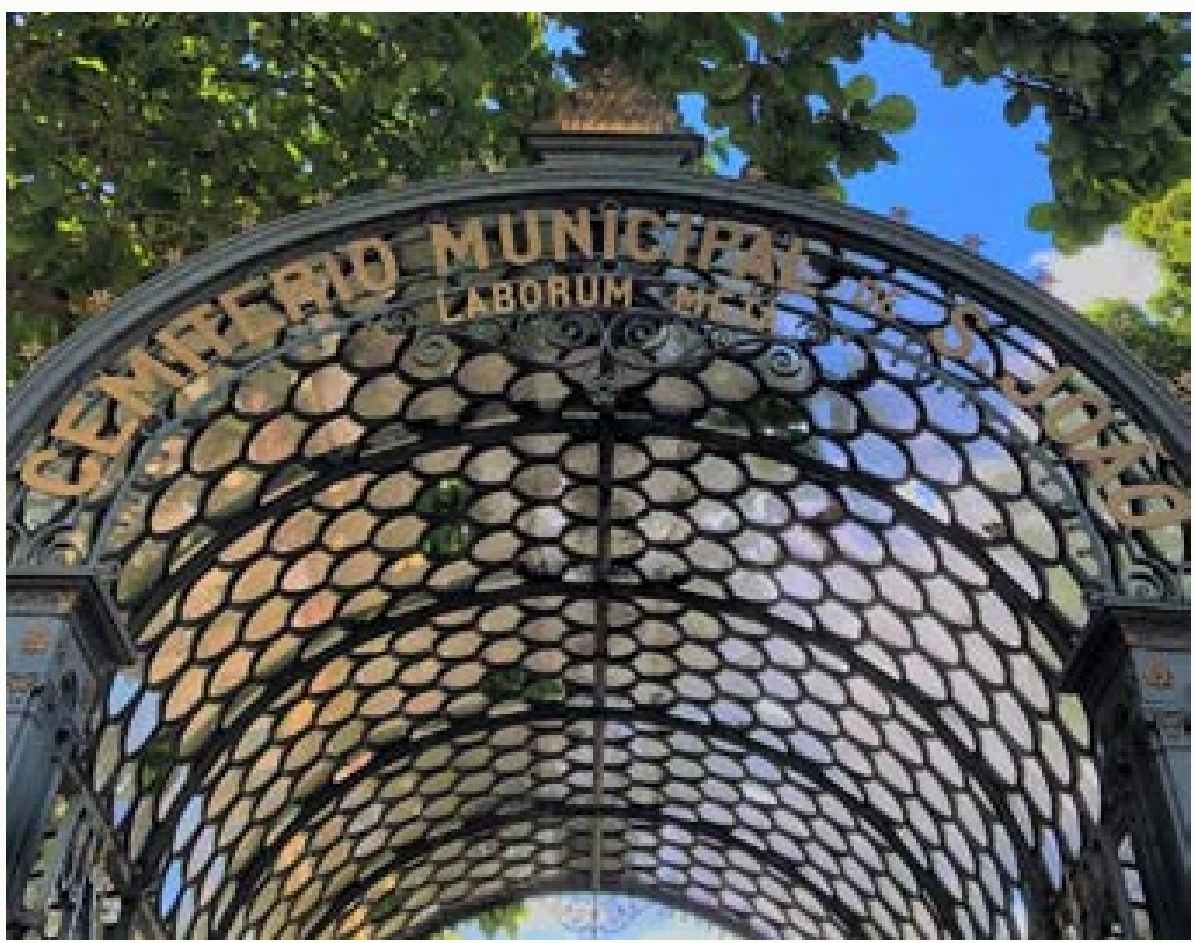

Fonte: Foto de Gabriel Yepez, 2019. Acervo dos Autores

23 Jornal Imparcial. Manaus, 04 de Outubro de 1918, p. 3. Disponível em: <http://memoria.bn.br/ DocReader/721212/727>. Acesso em: 13/09/2019.

24 JC. Manaus, 24 de Setembro de 1908, p. 4. Disponível em: <http://memoria.bn.br/DocReader/170054_01/6284> Acesso em: 13/09/2019.

25 JC. Manaus, 18 de Março de 1909, p. 4. Disponível em: <http://memoria.bn.br/DocReader/170054_01/6965>. Acesso em: 13/09/2019.

26 FREIRE, Ysy. Laborum meta. Disponível em: <https://www.recantodasletras.com.br/prosapoetica/4730846>. Acesso em: 30/08/2019. 
Para esta pesquisa foram realizadas cinco visitas ao Cemitério Municipal de São João, entre abril e julho de 2019, quando foram identificados, selecionados e pré-inventariados as obras escultóricas que interessam ao estudo. Foram consideradas obras: 1) Tridimensionais, uma vez que relevos existentes não são independentes da estrutura tumular e variam de qualidade; 2) Com a figura humana ou sugestão antropomórfica; 3) Elaboradas e instaladas no período que compreende o intervalo entre as últimas três décadas do século XIX, até o fim dos anos 20 do século XX. O conjunto de obras para análise contém 78 obras escultóricas. A partir desse recorte pretende-se compreender os grupos sociais envolvidos com este cemitério, como os comitentes de obra, os homenageados por elas, os escultores e artistas decoradores e os grupos sociais que dialogam com os valores transmitidos pelo exercício dessa expressão artística.

A seleção das obras para este artigo nem sempre pôde contar apenas com critérios temporais. Em muitos casos não é possível identificar a data exata da escultura, havendo apenas que estimá-la com base na data de falecimento. Assim, a seleção seguiu também critérios de estilo, que permitiram compor um caráter harmônico e caracterizar o objeto de estudo para reunir o conjunto das obras a serem analisadas: obras tridimensionais com argumentos que dialogam, interligadas pela presença do elemento antropomórfico. Nesse conjunto é possível identificar categorias internas que servem de caminhos a serem seguidos para a análise. Entre essas categorias estão as obras que destacam anjos (onde se inserem os anjinhos em grande número), crianças (não representadas como anjos), figuras femininas diversas e as esculturas que personificam a imagem do morto, destacando algum atributo pelo qual era conhecido.

Foram selecionadas 78 esculturas para compor o objeto deste estudo. A maioria está localizada nas quadras 1 a 10, mais próximas dos dois portões principais do cemitério e onde se encontram as sepulturas mais antigas. Apesar de o Cemitério ser tombado como patrimônio do estado, atestando-se assim seu valor histórico-artístico, não há evidências de cuidado na sua conservação. Tal negligência é comprovada pelo estado precário de muitas das obras escultóricas do período aqui investigado. O mármore, material mais usual na composição das obras, é particularmente suscetível às intempéries do clima úmido da região, demandando cuidado constante, que não é dispensado, excetuando-se alguns exemplares, que provavelmente recebem apenas diretamente dos donos dos jazigos.

Do conjunto de esculturas selecionadas, 65 apresentam alguma identificação do destinatário, sejam dos próprios falecidos ou de suas famílias. Em 18 há informação acerca da origem - a marmoraria e/ou o artista responsável -, sendo que muitas das outras estão com a base da sepultura danificada ou modificada, impossibilitando esse tipo de reconhecimento. Algumas contém identificação de proveniência de cidades brasileiras ou estrangeiras, como São Paulo, Gênova e Lisboa.

Em relação aos temas, os anjos, dentre os quais os querubins e as crianças pequenas com asas de anjos são os mais frequentes nesta cidade dos mortos, constituindo 49 do total de obras selecionadas. Maria Elízia Borges (2002, p. 182) afirma que nos séculos XIX e XX a figura 
do anjo é apropriada como guardião dos túmulos.

Mediadores entre o céu e a terra, os anjos e os arcanjos adultos ocuparam posição privilegiada na decoração tumular. Suas fisionomias se alteravam em função do estado de tristeza ou de alegria que se pretendia comunicar: ora anunciadores, ora tomados pelo êxtase, de alma exultante; ora repletos de esperança, de alma liberta; ora abatidos pela desolação, e outras intermitências da alma romântica. A expressividade era também realçada pelo movimento de suas asas: em repouso, fechadas, inclinadas, semiabertas, prestes a alçar voo (Mota, 2010, p. 63).

Na Figura 6 verifica-se uma representação do anjo Gabriel, facilmente identificável pela trombeta que sempre tem consigo, pois é o anjo que deverá fazer soá-la, anunciando o juízo final (Snider, 2017, p. 119). Algumas esculturas chegam a mostrá-lo prestes a fazê-lo, mas frequentemente ele está com o instrumento junto de si, aguardando, como é o caso do exemplo apresentado. Esta escultura é baseada em uma famosa escultura do italiano Giulio Monteverde, criada em 1882 para o túmulo do comerciante Francesco Oneto, no Cemitério de Staglieno, em Gênova (Bochicchio, 2012, p. 80). A obra original é conhecida como Angelo di Monteverde ou Angelo della Resurrezione. Na cópia identificada no Cemitério de São João, o anjo não tem traços femininos tão acentuados quanto os da escultura original, mas se mantém a pose e a posição das asas, bem como a trombeta que segura junto de si. 
Figura 6. Autor não identificado, escultura de anjo baseada no anjo de Monteverde/ da ressurreição, ${ }^{27}$ c. 1900

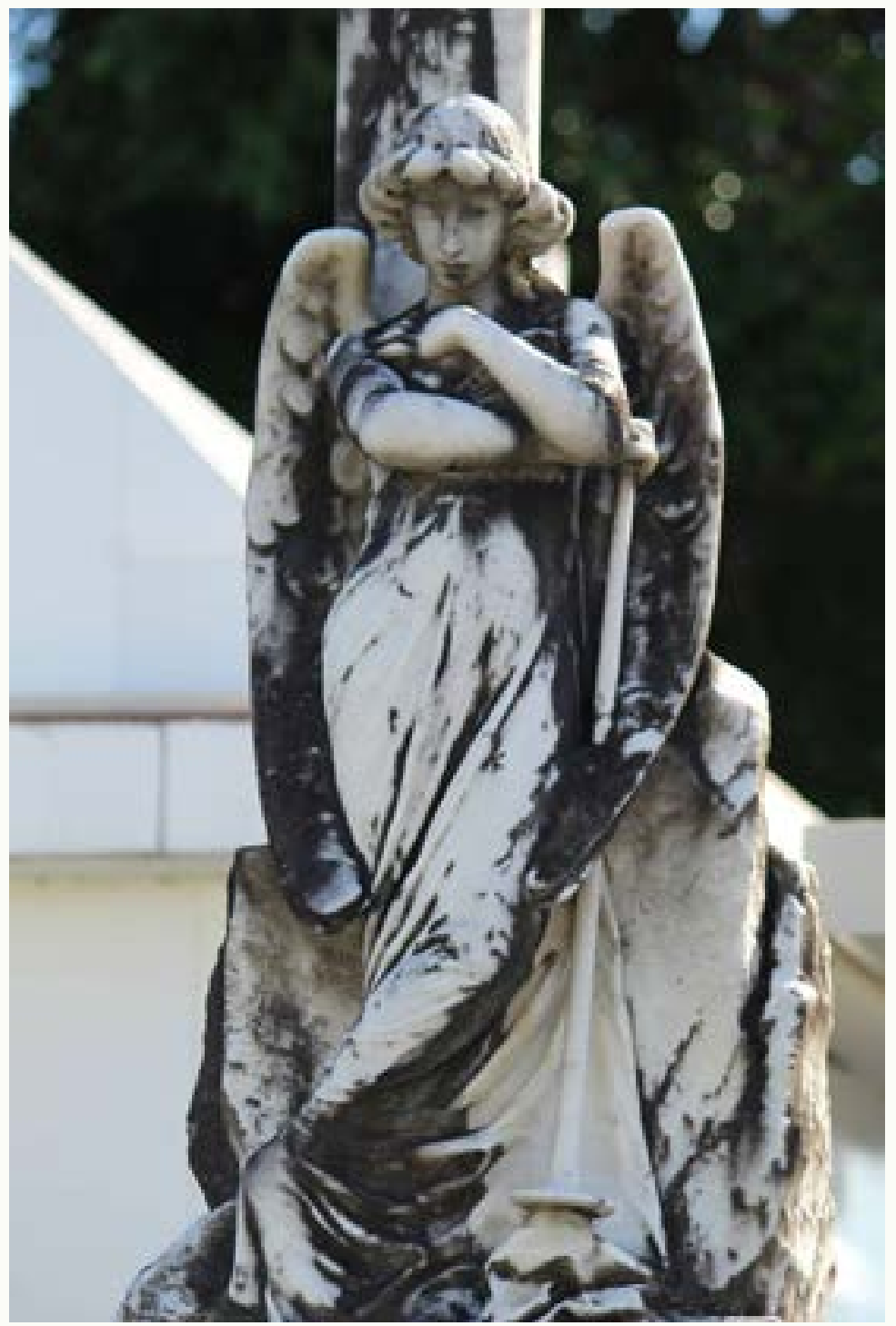

Fonte: Cemitério Municipal de São João, Manaus-AM, quadra 10. Foto de Yama Passos, 2019. Acervo dos autores.

Ao fazer alusão à análise do crítico de arte Franco Sborgi, Luca Bochicchio (2012, p. 80) afirma ter sido este anjo criado para representar tanto o anjo do dia do julgamento quanto o tipo de anjo com características mais femininas que marca presença na escultura funerária cristã a partir da segunda metade do século XIX.

Pouco tempo depois, a imagem criada por Monteverde se tornou um tipo de modelo padrão para a representação do mistério da morte por todo o mundo ocidental. Pesquisas têm demonstrado sua difusão em cemitérios europeus (da Romênia à Espanha, da França à Inglaterra)

27 Enfatiza-se que os títulos das obras não são originais, tendo sido atribuídos pelos autores no processo de identificação das mesmas para fins de análise interpretativa. 
bem como nas Américas do Norte e do Sul (Bochicchio, 2012, p. 80). ${ }^{28}$

Maria Elízia Borges, em seus estudos sobre a arte funerária no Brasil, também identificou uma escultura similar à de Monteverde no Cemitério de São João Batista, no Rio de Janeiro-RJ, e assinada por Achille Canessa. ${ }^{29}$ Recorrentes no Cemitério Municipal de São João são também as representações de querubins, mais especificamente tratando-se da imagem convencionada a partir do Renascimento de uma criança do sexo masculino, aparentemente com não mais de 7 anos de idade, desnuda e com asas (Figura 7), e crianças pequenas sem atributos não terrenos (Figura 8), muitas vezes também com asas de anjos. Os querubins e as crianças representadas como anjos somam 28 do total de 49 esculturas, sendo a maioria com características de produção escultórica a partir de modelo que permitiu várias cópias, conforme verifica-se nas réplicas encontradas no mesmo campo. Estas representações se tornaram populares durante a era vitoriana, em substituição ou adição às figuras de rostos com asas que costumavam simbolizar a ascensão da alma aos céus (Snider, 2017, p. 102).

Figura 7. Autor não identificado, querubim em prece, c. 1897

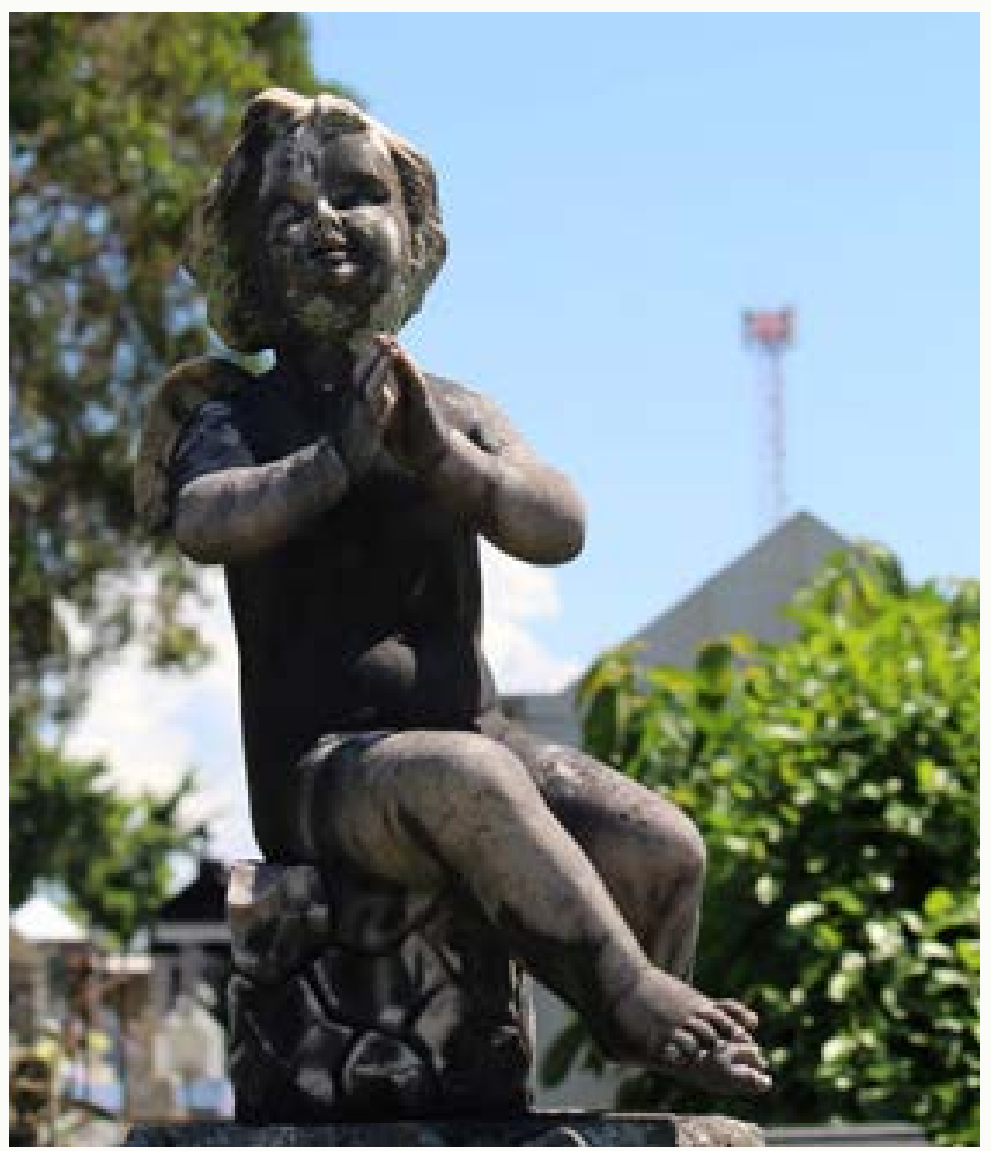

Fonte: Cemitério Municipal de São João, Manaus-AM, quadra 8 Foto de Yama Passos, 2019. Acervo dos autores.

28 Trecho original: "Before long, the icon created by Monteverde became a sort of standard model for the representation of the mystery of death all over the Western world. Research has demonstrated its diffusion in European cemeteries (from Romania to Spain, from France to England) as well as in those of both North and South America". (Tradução dos autores).

29 Cemitério São João Batista Rio de Janeiro (Rio de Janeiro - RJ). Disponível em: <https://www.artefunerariabrasil. com.br/camiterio/cemiterio-sao-joao-batista-rio-de-janeiro/\#galeria>. Acesso em: 06/01/2020. 
Figura 8. Autor não identificado, escultura de criança carregando flores, sem data

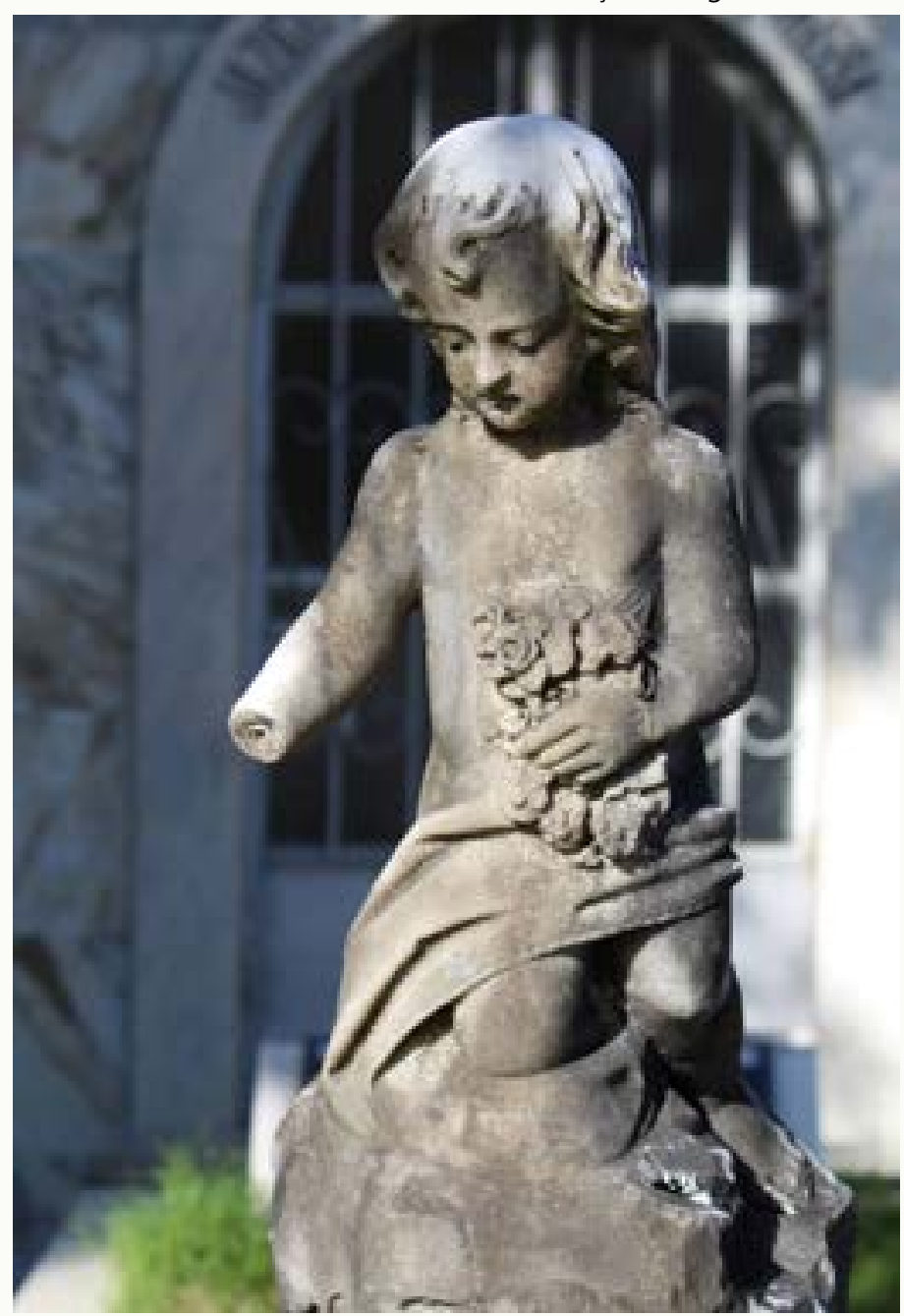

Fonte: Cemitério Municipal de São João, Manaus-AM, quadra 8. Foto de Yama Passos, 2019. Acervo dos autores.

Crianças em esculturas tumulares são também "símbolos de inocência e a fatalidade de vidas ceifadas precocemente" (Nabozny e Liccardo, 2017, p. 30), razão pela qual em muitos casos marcam o lugar do túmulo de um inocente ou anjinho, como eram chamadas as crianças que faleciam antes de completar sete anos, o que significa sem a mácula do pecado como acreditava-se. Portanto, com a salvação garantida. A morte de crianças pequenas se deveria evitar chorar, como consta no poema de Álvares de Azevedo:

Não chorem... que não morreu!

Era um anjinho do céu que outro anjinho chamou!

Era uma luz peregrina,

Era uma estrela divina

Que ao firmamento voou! (Azevedo, 2007, p. 12).

"Ainda durante o século XX, a morte infantil era vista como algo positivo, mesmo com a carga de dor. Com a criança morta, em especial até idade de sete anos, a família poderia contar, 
a partir de então, com um 'anjo' próximo, um intercessor no mundo celestial" (Gawryszewski, 2016, p. 297-298). Para Luis Vailati, a morte infantil, diante da ideia da pureza da criança desde que esta pertencesse a um lar cristão e fosse batizada - caracterizava-se por uma gravidade atenuada, "seja pela ausência de luto e pela descontração dos participantes, seja pela presença de elementos comuns às manifestações festivas" (Vailati, 2010, p. 306). O autor enfatiza que as manifestações de dor pela morte das crianças eram efetivas, não se duvidando de que as crianças fossem consideradas importantes. Ainda segundo ele, a tristeza usualmente restringia-se ao ambiente privado familiar, enquanto em público os ritos buscavam demonstrar conformidade com a vontade de Deus, e alegria pelo destino celestial da criança morta. Duarte (2018, p. 75) destaca que as festividades associadas ao funeral dos anjinhos integravam um discurso popular que extrapolava a retórica oficial da igreja católica.

A composição da Figura 9 representa o que é destacado pelos autores. Nela, dois anjinhos estão sentados numa nuvem e olham para o céu, com as mãos em prece. As inscrições abaixo da obra auxiliam a compreensão de que retrata duas crianças da mesma família mortas com idade de anjos. "Suas almas no céu oram a Deus por seus pais", diz o epitáfio.

Figura 9. Autor não identificado, anjinhos em atitude de oração, c. 1891

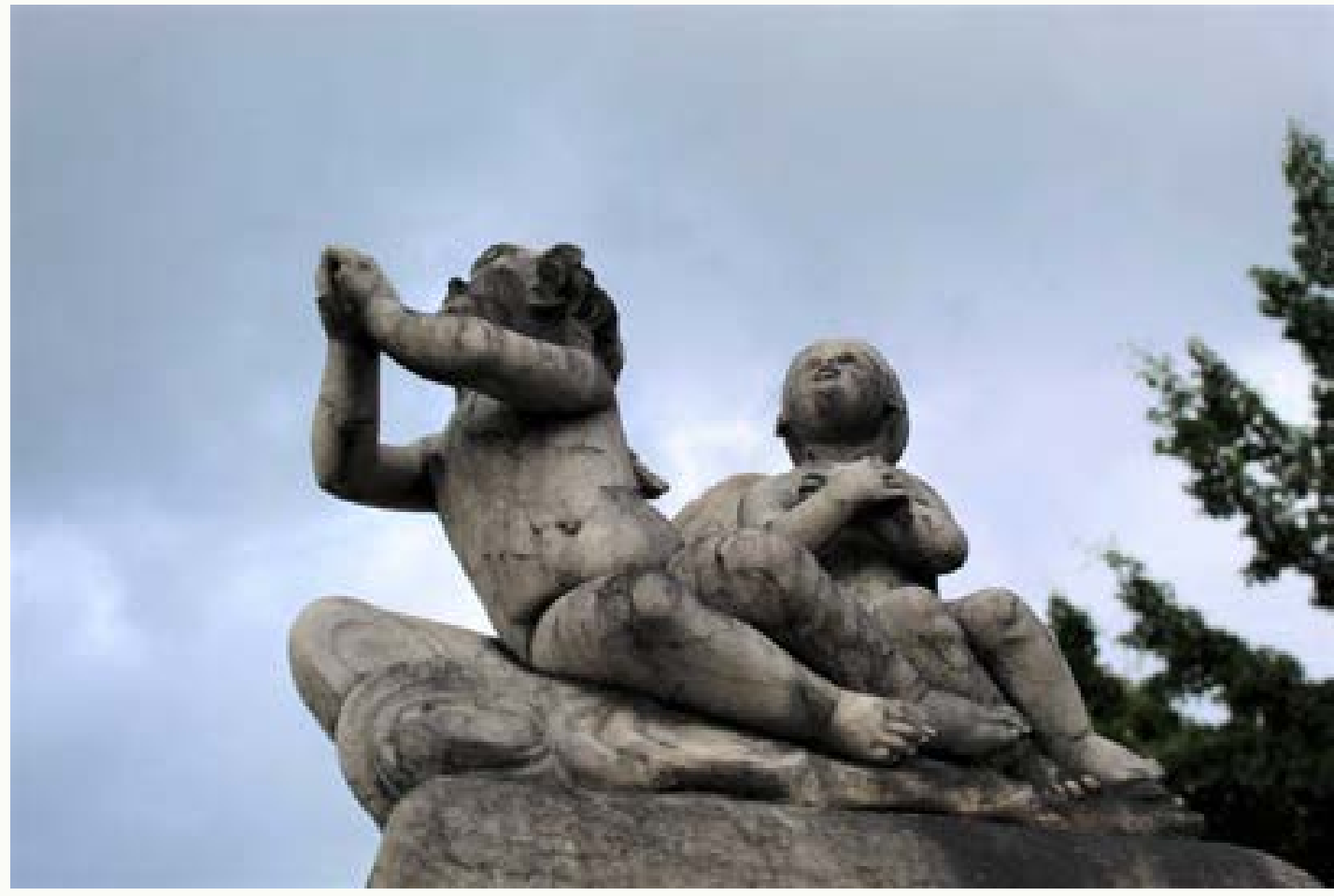

Fonte: Cemitério Municipal de São João, Manaus-AM, quadra 4. Foto de Gabriel Yepez, 2019. Acervo dos autores.

Os anjos adultos, inicialmente representados como seres alados e assexuados, foram cada vez mais humanizados, ganhando aparência mais terrena (Borges, 2002, p. 182). Mota (2010, p. 63) destaca a ênfase nas figuras femininas, que passam a assumir o lugar de guardiãs dos túmulos, com o avanço da laicização dos cemitérios, no início do século XX. 
Várias são as figuras femininas transmutadas em anjos, contudo, sem perderem a sensualidade, implicitamente sugerida ou visivelmente realçada.

[...]

Em alguns cemitérios europeus, coincidindo com o apogeu da chamada belle époque, a arte funerária conheceu um periodo bastante criativo, dando vazão às fantasias românticas profanas, fortemente erotizadas, seja através da figura de anjos feminilizados, seja por meio da própria representação do corpo feminino que, a partir de então, tornou-se onipresente em diferentes formas alegóricas tumulares (Mota, 2010, p. 63).

Uma das alegorias de anjos com formas femininas identificadas no Cemitério de São João é a da saudade. Nesse tipo de alegoria, "o anjo apresenta-se em estado de meditação, com expressão triste e serena" (Borges, 2002, p. 185), podendo apresentar-se de várias maneiras. $\mathrm{Na}$ escultura aqui usada como exemplo (Figura 10), a mulher com asas de anjo se encontra sentada em frente a uma estrela, suas mãos juntas sobre o colo e o olhar entristecido voltado para o céu. Ao mesmo tempo em que transmite uma atitude de luto e oração, sua sensualidade está implicitamente sugerida, por certos elementos, como a proeminência dos seios sob as vestes, que realçam seus contornos femininos, os braços e pés desnudos. 
Figura 10. Sartorio, Alegoria da saudade, sem data

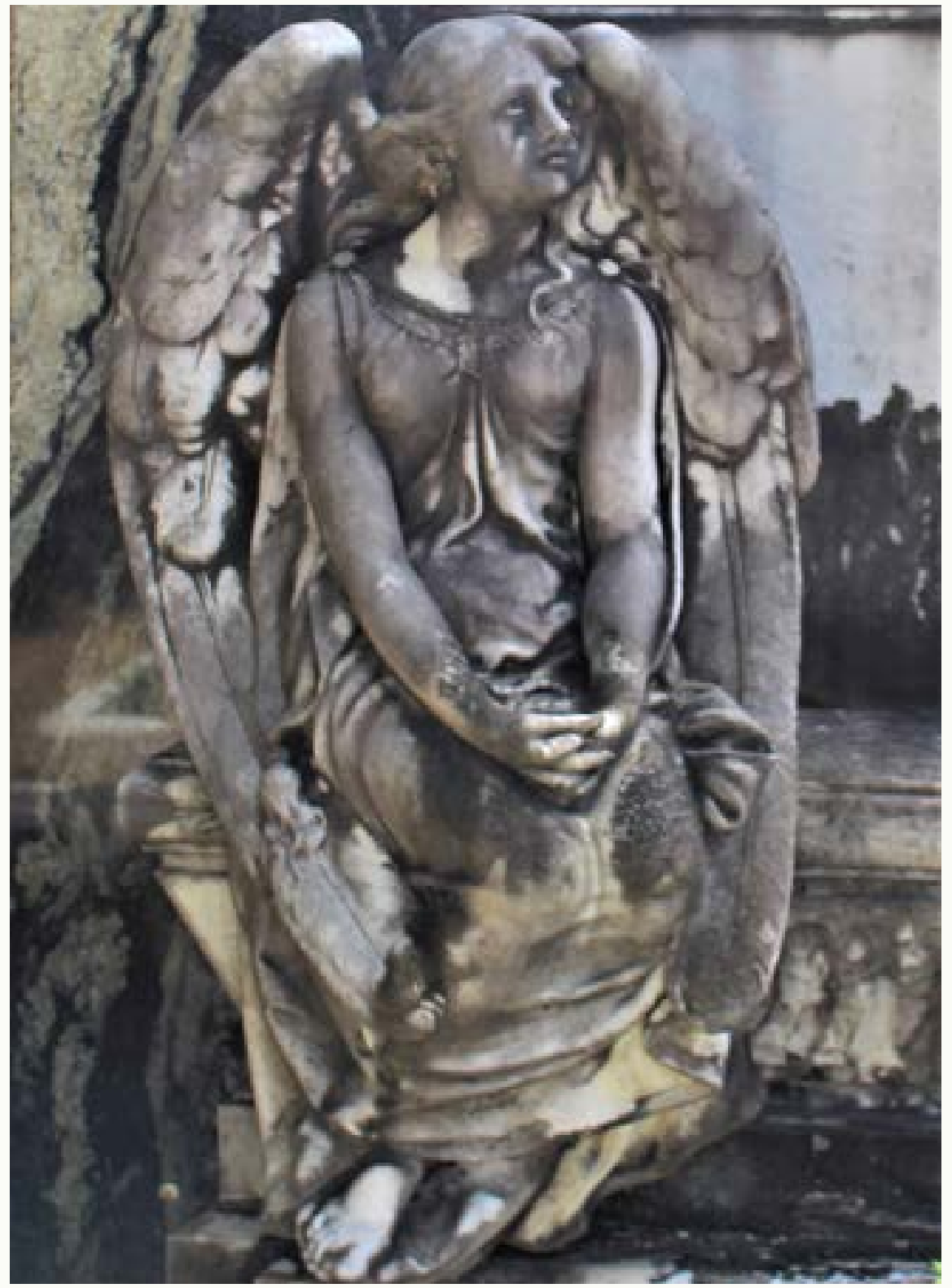

Fonte: Cemitério Municipal de São João, Manaus-AM, quadra 2. Foto de Gabriel Yepez, 2019. Acerbo dos Autores.

Ariès aponta um fenômeno ocorrido entre os séculos XVI e XVIII, que propiciou que temas artísticos mortuários adquirissem fortes características eróticas, em uma aproximação entre Eros e Tânatos derivada de uma nova ideia difundida, da morte como transgressão, assim como o ato sexual, ideia ainda presente na sociedade conservadora do século XIX, que institui o cemitério como busca de controlar a morte (Ariès, 2017, p. 65).

Carneiro (2016, p. 32) destaca que o projeto de civilidade abrangia também a instituição de regras para o comportamento das pessoas, a partir da difusão de normas sociais relacionadas a cada gênero. Homem e mulher, cada um contava com papeis específicos, a cumprir em sociedade. Nesse cenário, à mulher cabia o papel de esposa e mãe, cuidadora e passiva. Por outro lado, o feminino também não deixa de estar vinculado ao imaginário erótico 
de uma sociedade em que a repressão era a norma, e a imagem da mulher em representações artísticas deixa entrever o caráter antitético de sua condição. "A céu aberto e secularizados, os cemitérios propiciam a instalação de obras com maior liberdade expressiva" (Carneiro, 2016, p. 299). Desse modo, o campo santo torna-se solo fértil para a representação da dualidade da ideologia burguesa em relação à figura da mulher, por um lado associada à proteção familiar, ao acolhimento materno, por outro, representativa do amor erótico.

A obra da Figura 10 contém elementos de identificação de procedência autoral e geográfica, assinada "G. Sartorio - Roma". O autor, Giuseppe Sartorio (1854-1922), artista italiano nascido em Boccioleto e conhecido especialmente pela produção de monumentos fúnebres, com grande variedade de obras de sua autoria em cemitérios italianos, principalmente na região da Sardenha, como Cagliari e Sassari, mas também em Roma, onde ele manteve duas oficinas a partir de 1890, origem da obra localizada no Cemitério de São João, em Manaus.

Sartorio, cuja arte escultórica teve como característica marcante a representação realista fotográfica das feições dos sujeitos reais aos quais produzia os monumentos - talento que the rendeu o título de "Michelangelo dos mortos", 30 voltou-se no século XX para figuras angelicais e femininas de inspiração pré-rafaelita, adequando-se a uma variação de gosto de seus clientes (Gaias, 2012, p. 129-130). É provável que a escultura aqui exibida se situe nesse período de criação, uma vez que não há indicação de data junto à assinatura e, também, a sepultura já não conta mais com informações a respeito de seus ocupantes.

A escultura da Figura 11 representa uma alegoria da saudade, que exprime a presença feminina nos cemitérios do período e, ainda, realça o valor concedido à individualidade do morto característico da morte burguesa. Trata-se de uma mulher de cabeça baixa, envolvendo com o braço direito uma cruz alta, e segurando uma grinalda com a mão esquerda. A indumentária e o penteado, típicos da época, e a aliança na mão que segura a grinalda sugerem a possibilidade de tratar-se da representação de uma mulher real, talvez a própria falecida que ali repousa.

30 POLASTRI, Marcello. Sartorio, fascino e mistero del Michelangelo dei morti. Sardegna Sotterranea. 31 de Outubro de 2018. Disponível em: <http://www.sardegnasotterranea.org/sartorio-fascino-e-mistero-del-michelangelo-deimorti/>. Acesso em: 13/09/2019. 
Figura 11. Autor não identificado, alegoria da saudade com representação personalizada, c. 1906

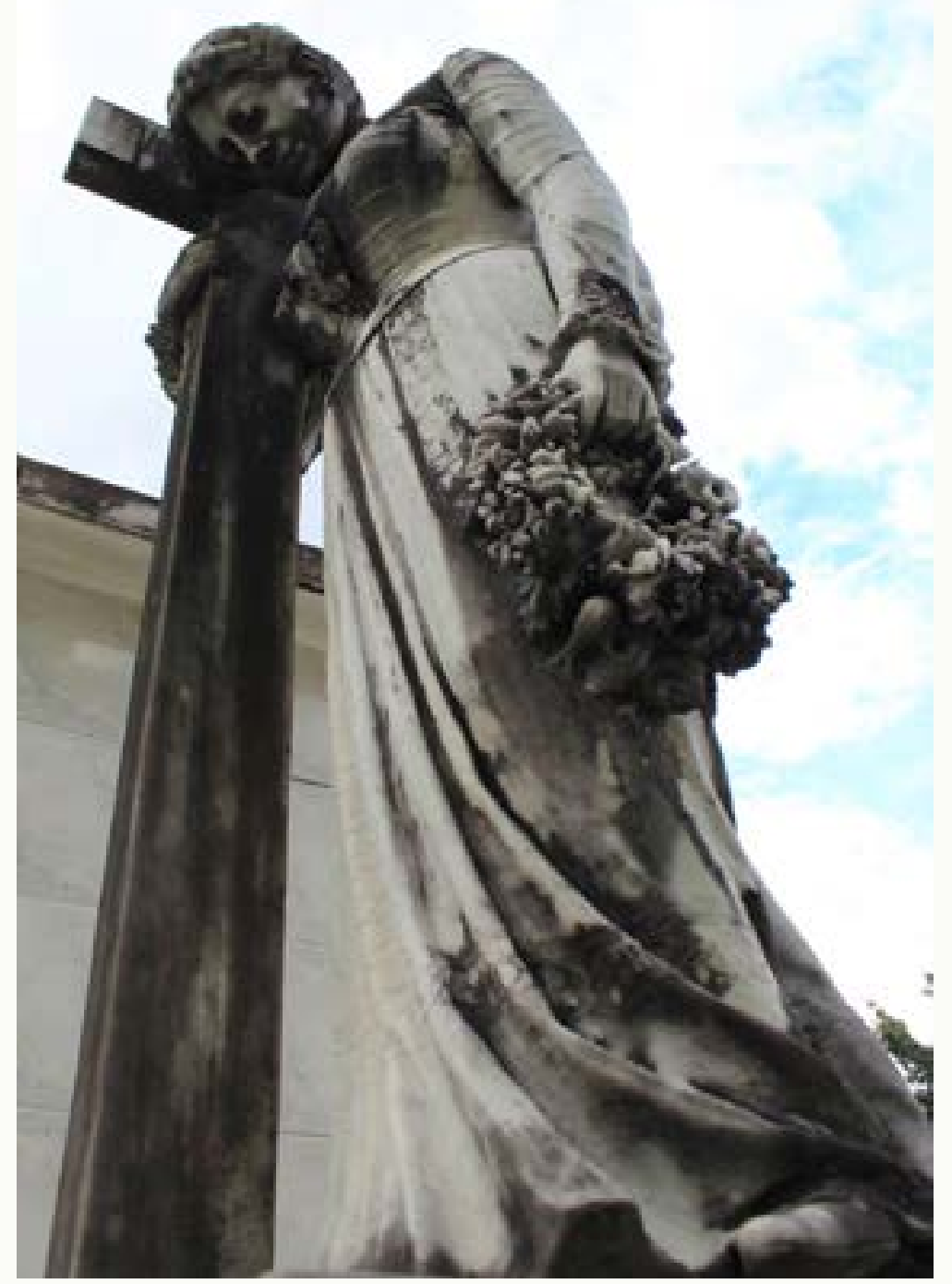

Fonte: Cemitério Municipal de São João, Manaus-AM, quadra 5. Foto de Gabriel Yepez, 2019. Acervo dos autores.

A representação da imagem do morto na arte tumular associa-se diretamente com o sentimento de negação da morte defendido por Ariès (2017, p. 74). Negação no sentido de que a vontade de perpetuação da memória do morto indica uma recusa em aceitar sua partida definitiva. Tal pensamento estaria presente na humanidade desde o despertar da consciência da morte, como é apontado por Morin (1997, p. 25) e Panofsky (2017, p. 10). A consciência da morte vem acompanhada de um sentimento contraditório de negação desta, uma vez que sua ritualização surge da crença em algum tipo de continuação da vida além da morte. No século XIX, ao mesmo tempo em que se exalta a morte por intermédio do romantismo, estabelecia-se uma cultura de perpetuação da memória do morto que caracterizava uma demanda humana de eternização que se materializa de forma exuberante no solo cemiterial na contramão de sua mortalidade. 


\section{Considerações finais}

A consciência da morte adquirida pelo homem em tempos primitivos fez com que este desenvolvesse um aparato cultural e religioso para lidar com sua condição, aproximando-o do sobrenatural. A partir da crença de que a morte não significava o fim de sua existência, as práticas mortuárias refletem um cuidado que considera o pós-vida do defunto. Entre essas práticas, essa pesquisa destaca a presença da escultura, que cria representações de demandas do morto, de modo a conter sua ameaça e garanti-lo como aliado, num temor que diviniza sua figura.

No século XIX, os cemitérios são planejados como cidades para os mortos e expressam a ideologia de uma época marcada pela racionalidade positivista, pela ascensão burguesa, dimensão do Romantismo e seus subgêneros, posicionados aqui conforme o aprofundamento das questões espirituais do tempo e da visão metafísica do assunto. Essas cidades dos mortos são povoadas por estátuas, guardiãs das últimas moradas dos mortos, mas também por uma imagem social dos vivos que lhes dizem respeito, aqui tidas como elo de ligação entre os dois mundos, que propicia um entendimento do espírito da época.

As reflexões empreendidas sobre o objeto desta análise permitem confirmar a presença de um programa estético vinculado a valores socialmente vigentes no século XIX, sob a égide do projeto da Modernidade, no Cemitério Municipal de São João, numa Manaus que buscava interlocução com importantes parceiros externos, social, comercial e culturalmente. A pesquisa avança, na direção da identificação de artistas tumulares, de grupos comerciais que atuaram em seu nome, de famílias clientes destes negócios e, ainda, aspectos da recepção pública a estas obras, para o aprofundamento da análise.

\section{Referências Bibliográficas}

ARIĖS, Philip. A história da morte no ocidente: da idade média aos nossos tempos. Tradução Priscila Viana de Siqueira. Rio de Janeiro: Nova Fronteira, 2017. 289p.

AZEVEDO, Álvares de. Lira dos vintes anos. São Paulo: Ciranda Cultural Editora e Distribuidora Ltda., 2007. 159p.

BITTENCOURT, Agnello. Fundação de Manaus: pródromos e sequências. 2. ed. Manaus: EDUA, 1999. 53p.

BOCHICCHIO, Luca. Transported art: 19th-century italian sculptures across continents and cultures. Material Culture Review. Sydney, n. 74-75, p. 70-85, primavera, 2012. Disponível em: <https://pdfs.semanticscholar.org/deb6/f7ce2dc2a04bef919f6b2e001ed4ecdd70f7.pdf? = $\mathrm{ga}=2.194675821 .1921797076 .1578319386-1928607906.1578319386>$. Acesso em: 06/01/2020.

BOIS, Pedro Du. O Senhor das estátuas. Guaratinguetá/SP: PENALUX, 2013. 90p.

BORGES, Maria Elízia. Arte funerária no Brasil (1890-1930): ofício de marmoristas italianos em 
Ribeirão Preto. Belo Horizonte: C/Arte, 2002. 312p.

CAMPBELL, Joseph. As Máscaras de Deus: mitologia primitiva. Tradução Carmen Fischer. vol. 1. $7^{\circ}$ ed. São Paulo: Palas Atena, 2005. 424p.

CARNEIRO, Maristela. Desnudando a masculinidade: representações de nudez e seminudez na estatuária funerária paulistana (1920-1950). Dissertação (Mestrado em Sociedade, Direito e Cidadania). Programa de Pós-Graduação em História, Universidade Federal de Goiás, Goiânia, 2016. 349p. Disponível em: <https://tede2.uepg.br/jspui/handle/prefix/332>. Acesso em: 30/12/2019.

COE, Agostinho Júnior Holanda. "Nós, os ossos que aqui estamos, pelos vossos esperamos": a higiene e o fim dos sepultamentos eclesiásticos em São Luís (1828 - 1855). Dissertação (Mestrado em História Social) Programa de Pós-Graduação em História Social do Centro de Humanidades, Universidade Federal do Ceará, Fortaleza, 2008. 140p. Disponível em: $<$ http://www.repositorio.ufc.br/bitstream/riufc/2841/1/2008_dis_ajholanda.pdf>. Acesso em: 14/09/2019.

DUARTE, Denise Aparecida Souza. Em vida inocente, na morte "anjinho": morte, infância e significados da morte infantil em Minas Gerais (séculos XVIII-XX). Tese (Doutorado em História). Programa de Pós-Graduação em História da Faculdade de Filosofia e Ciências Humanas, Universidade Federal de Minas Gerais, Belo Horizonte, 2018. 379p. Disponível em: <https:// repositorio.ufmg.br/handle/1843/BUOS-B9BJ7G>. Acesso em: 26/12/2019.

DUARTE, Durango. Manaus entre o passado e o presente. Manaus: Mídia Ponto Comm, 2009. $296 p$.

FRANCO, Clarissa de. A Cara da Morte: os sepultadores, o imaginário fúnebre e o universo onírico. Aparecida - SP: Ideias e Letras, 2010. 260p.

GAIAS, Marisa Porcu. Enrico Costa e Giuseppe Sartorio e l'esaltazione dele virtù patrie e private. In: BRIGAGLIA, Manlio; BAGELLA, Stefania e MANNUZU, Salvatore. Enrico Costa (1841-1909):Società, politica e cultura tra otto e novecento. Sassari: Mediando, 2012, p. 229241.

GAWRYSZEWSKI, Alberto. A representação da morte infantil em imagens cemiteriais no Brasil (séculos XIX e XX). História: Debates e Tendências. Passo Fundo, v. 16, n. 2, p. 291-313, jul./ dez. 2016. Disponível em: <http://seer.upf.br/index.php/rhdt/article/download/6919/4136/0>. Acesso em: 14/09/2019.

JAFFÉ, Aniela. O simbolismo nas artes plásticas. In: JUNG, Carl G. O homem e seus símbolos. Tradução Maria Lúcia Pinto. 2 ed. Rio de Janeiro: Nova Fronteira, 2008, p. 312-367.

LIGHTMAN, Alan. Sonhos de Einstein. Tradução Marcelo Levy. São Paulo: Companhia de Bolso, 2014. 103p.

LYOTARD, Jean-François. O Pós-Moderno. Tradução Ricardo Corrêa Barbosa. 3. ed. Rio de Janeiro: Editora José Olympio, 1991, 123p.

MESQUITA, Otoni Moreira de. Manaus: história e arquitetura - 1852-1910. $3^{\circ}$ ed. Manaus: Editora Valer, Prefeitura de Manaus e Uninorte, 2006. 360p. 
MORIN, Edgar. O Homem e a morte. Tradução João Guerreiro Boto e Adelino dos Santos Rodrigues. Lisboa: Europa - América, 1997. 327p.

MOTA, Antonio. Estilos mortuários e modos de sociabilidade em cemitérios brasileiros oitocentistas. Horizontes Antropológicos. Porto Alegre, ano 16, n. 33, p. 55-80, jan./jun. 2010. Disponível em: <http://www.scielo.br/pdf/ha/v16n33/05.pdf>. Acesso em: 14/09/2019.

NABOZNY, Almir e LICCARDO, Antonio. Estética da morte: paisagens de cemitérios. Ponta Grossa - PR: Estúdio Texto, 2017. 64p.

NAGEL, Carla Maria Oliveira. A morte e o morrer na "Paris dos Trópicos". Anais Eletrônicos do XXVI Simpósio Nacional de História. São Paulo, ANPUH Nacional, 2011. Disponível

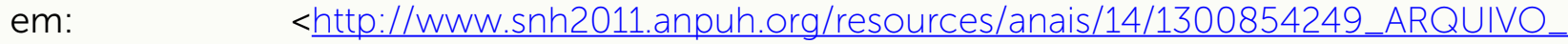
AMorteeoMorrernaParisdosTropicossemresumoeabstract.pdf> Acesso em: 04/09/2019.

PANOFSKY, Erwin. Tomb sculpture: four lectures on its changing aspects from ancient Egypt to Bernini. New York: Harry N. Abrams, Inc., 1992. 319p.

PANOFSKY, Erwin. Estudos de iconologia: temas humanísticos na arte do renascimento. Tradução Olinda Braga de Sousa. 2. ed. Lisboa: Editorial Estampa, 1995. 237p.

PANOFSKY, Erwin. Significado nas artes visuais. Tradução Maria Clara F. Kneese. 4. ed. São Paulo: Perspectiva, 2017. 440p.

SANTOS, Boaventura de Sousa. Gramática do tempo: para uma nova cultura política. 3 ed. São Paulo: Editora Cortez, 2010. 512p.

SNIDER, Tui. Understanding cemetery symbols: a field guide for historic graveyards. Texas: Castle Azle Press, 2017. 250p.

VAILATI, Luis Lima. A morte menina: infância e morte infantil no Brasil dos oitocentos (Rio de Janeiro e São Paulo). São Paulo: Editora Alameda. 2010. 358p.

VATTIMO, Gianni. A sociedade transparente. Lisboa: Relógio D’Água. 1992. 83p.

VATTIMO, Gianni. O fim da modernidade: niilismo e hermenêutica na cultura pós-moderna. São Paulo: Martins Fontes, 2002. 207p.

Recebido em: 15 de setembro de 2019

Aprovado em: 22 de dezembro de 2019 